\title{
Understorey changes after an extreme drought event are modulated by overstorey tree species mixtures in thermophilous deciduous forests
}

\author{
Giovanni Iacopetti $^{\text {a }}$, Filippo Bussotti ${ }^{\text {a }}$, Elisa Carrari ${ }^{\text {a, }}{ }^{*}$, Sofia Martini $^{\text {b }}$, Federico Selvi ${ }^{\text {a }}$ \\ ${ }^{\text {a }}$ Department of Agriculture, Food, Environment and Forestry, Laboratories of Applied and Environmental Botany, University of Firenze, Piazzale delle Cascine 28, I- \\ 50144 Florence, Italy \\ ${ }^{\mathrm{b}}$ Department of Agriculture, Food, Environment and Forestry, University of Firenze, Via San Bonaventura 13, 50145 Firenze, Italy
}

\section{A R T I C L E I N F O}

\section{Keywords:}

Extreme climate events

FunDivEUROPE

Herbaceous layer

Mediterranean woodlands

Mixed forests

Plant diversity

\begin{abstract}
A B S T R A C T
Understorey vegetation is a key component of plant biodiversity in forests. Events of extreme drought are a potential major driver of change of this layer. Although these are predicted to increase in frequency and duration due to climate change, their impacts on understorey communities are still unknown. In this paper, we resurveyed a set of 36 plots in mature thermophilous deciduous forests eight months after the end of an extremely dry period in 2016-2017. The plots are part of a European network representing a gradient of overstorey richness from 1- to 5-tree species mixtures, with variable composition. We took advantage of this model system to test the hypothesis that species richness and identity of dominant trees in the overstorey may modulate the impact of drought on understorey cover, diversity and composition. In spring 2018, a ca. 50\% reduction of understorey cover occurred in both mono-specific and mixed plots. Species evenness and Shannon $\alpha$-diversity increased in the monospecific plots, due to a reduction of abundance of tree species at juvenile stage and the appearance of non-forest specialists that did not occur in the mixtures. Overstorey species identity effects on understorey diversity were negligible. Overall compositional changes were moderate, though larger in the mixed plots and in those with the less drought-adapted tree species in the overstorey. Ellenberg ecological profile of the community did not change significantly but light values tended to increase in the monospecific plots, contrary to the mixtures. Overall, our findings provide circumstantial support to a higher diversity stability in the understorey of mixed plots shortly after drought, despite compositional variations. More studies and monitoring programs are needed to assess understorey recovery capacity and resilience after such events in the long-term.
\end{abstract}

\section{Introduction}

Despite their negligible contribution to the total biomass of the forest (Welch et al., 2007), understorey plants represent up to $80 \%$ of the total species diversity in temperate woodlands (Gilliam, 2007). They support a number of ecosystem functions, such as nutrient and carbon cycling and energy flow, also acting as drivers of overstorey regeneration and succession (Hart and Chen, 2006; Thrippleton et al., 2016; Landuyt et al., 2019). Moreover, food and habitat resources are provided by many species of the lowest forest layer (Gilliam, 2014). Hence, maintaining the integrity of the understorey is increasingly acknowledged as a major goal in sustainable forest management and biodiversity conservation programs (Canullo et al., 2016). Due to their often high sensitivity to environmental conditions, understorey plants form dynamic communities that respond in many ways to a broad range of habitat changes and disturbances over both short and long time scales (Ares et al., 2009; Su et al., 2019; Kutnar et al., 2019).

Although the many drivers of global change are known to affect in multiple and interactive ways this forest layer, the potential impacts of extreme climate events have been overlooked in the recent literature. Frequency and duration of drought and heat episodes are indeed among the potential drivers of direct and overstorey-mediated changes in the structure of understorey communities (Archaux and Wolters, 2006; Felsmann, et al., 2018). Since current climate projections predict strong reductions of summer precipitation and an increase in the occurrence of drought periods all over Europe (IPCC, 2012; 2014), there is a need for interdisciplinary research initiatives on the short-term consequences of such events on forest biodiversity (Archaux and Wolters, 2006; Felsmann et al., 2018). However, observational and experimental evidence from studies focusing on understorey responses are still very scanty.

\footnotetext{
* Corresponding author.

E-mail address: elisa.carrari@unifi.it (E. Carrari).
} 
Ozolinčius et al. (2009) reported a strong reduction of ground vegetation cover in a pine forest after three years of drought, associated with a $20 \%$ decrease in Shannon diversity. Compositional shifts towards more xero-tolerant assemblages are also likely triggered by increasing duration of drought periods (Mueller et al., 2005), and thermophilization of the understorey due to global warming has been documented in European and North American forests (De Frenne et al., 2013). According to Allen et al. (2015), particularly hot droughts with a co-occurrence of high air temperatures, high atmospheric water vapour pressure deficit causing high evaporation, and soil water deficit due to reduced precipitation, will have a strong impact on forests ecosystems.

Advancing our understanding of the responses of the understorey in different forest types and by which factors these are modulated is therefore relevant to plan management that may mitigate the impacts. Overstorey characteristics such as cover, species richness and composition are among these potential factors, because of the strong influence that canopy trees have on the understorey via regulation of microclimate, light and soil conditions (Barbier et al., 2008; Landuyt et al., 2019). In closed forests, the understorey is thermally insulated by the overstorey, so that extremely low air humidity and high temperatures are not likely to occur close to the ground (Fotelli et al., 2003). De Frenne et al. (2013) and Zellweger et al. (2020) found that thermophilization of understorey vegetation due to macroclimate warming was attenuated in temperate forests with denser canopies, and Davis et al. (2019) showed that canopy buffering of temperature and vapor pressure deficit is greater in forests with higher levels of canopy cover. Moreover, it was also shown that forest density, structural complexity and tree species diversity are usually positively related with forest microclimate stability (Ehbrecht et al., 2017). However, whether the number and species identity of trees in the overstorey can affect the response of the understorey community during drought and heat periods has not been investigated so far. Both species richness and identity effects can be expected because dominant and subdominant canopy trees have a species-specific influence on resources availability and environmental conditions in the lower forest layers, including microclimate (Barbier et al., 2008; Wulf and Naaf, 2009; Ampoorter et al., 2015, 2016; Baeten et al., 2019). Depending on the species and their characteristics, canopy trees can variously affect water availability through water interception and evapotranspiration and by reducing wind speed, irradiation, temperature and vapour pressure deficit at the forest floor (Davis et al. 2019).

In a given region, therefore, monospecific stands of different species are likely to differ from each other in terms of microclimate, as well as the various mixed assemblages that they can form due to natural factors, forest management or a combination of both. Acquiring a better knowledge about the responses of the understorey in monospecific and mixed stands in the face of heat and drought periods can inform forest management aiming at preserving ecosystem functionality. In fact, drought susceptibility of the understorey community might be affected by silvicultural practices which usually impacts on the overstorey in terms of number and composition of tree species (Felsmann et al., 2018).

Here we adopted an observational approach to provide more insights into this question, by re-surveying the understorey of a tree diversityoriented network of plots in thermophilous deciduous forests of central Italy six years after the first survey (2012-2018). An episode of extreme drought and heat occurred in 2016-2017, which caused impressive effects on both evergreen and deciduous woody species at the regional scale, such as widespread defoliation, partial or total desiccation of crowns and dieback of tree branches (Puletti et al., 2019; Pollastrini et al., 2019). The evaluation of the short-term effects of this event on the understorey in relation to tree species richness and composition of the stands was allowed by the absence of direct anthropogenic disturbances and by the tree diversity gradient realized in the plot experimental design. While accounting for other nonanthropogenic disturbances to the overstorey potentially affecting the understorey, we could therefore address the following questions: 1) Was the abundance, diversity and composition of the understorey vegetation of thermophilous deciduous forests affected shortly after an extreme drought event? 2) Did overstorey species richness and/or species identity modulate these effects, if any? 3) What are the implications for forest management to mitigate the impact of these events on understorey diversity?

\section{Material and methods}

\subsection{Study site, sampling design and data collection}

The study area is located on the hills of central Tuscany in west peninsular Italy (Lat. $43.2^{\circ} \mathrm{N}$, Long. $11.2^{\circ} \mathrm{E}$; Fig. 1A). Vegetation data were collected in the network of $3630 \mathrm{~m} \times 30 \mathrm{~m}$ plots that are part of the FunDivEurope exploratory platform (http://project.fundiveurope. eu/) and representative of the category "thermophilous deciduous forests" as defined in the European Environment Agency classification (EEA), which covers large areas in Italy (ca. $40 \%$ of the national forest surface in Italy; Barbati et al., 2007). The plots were included in mature stands that originated from the abandonment of the traditional coppice management at least 50 years ago; these are mostly included in nature reserves owned by Regione Toscana and/or in the Rete Natura 2000 sites (Bussotti et al., 2012). Direct anthropogenic disturbances possibly affecting the understory are virtually absent, since no active management is adopted in these stands and forest vegetation is left to its natural dynamic development since decades.

All details about the guiding criteria of the experimental design of the FunDivEurope exploratory platform and the selection of plots can be found in Baeten et al. (2013). To sum up, our plots were selected to cover a tree species richness gradient from 1 to 5 dominant tree species, named "focal trees": Castanea sativa Mill., Ostrya carpinifolia Scop., Quercus cerris L., Q. ilex L. and Q. petraea (Matt.) Liebl. The number of plots for each species richness level was 10 (monospecific stands), 9 (each for 2sp. and 3-sp. mixtures), 7 (4 sp. mixtures) and 1 (5-sp. mixtures). For the purpose of this work, the only 5-species mixture plot was pooled together with the 4-species plots, as in Coppi et al. (2019). Each species richness level was replicated with different species combinations of these trees, to separate species diversity from composition effects; the 27 species combinations represented in our design and the frequency of each species in the four richness levels are given in Supplementary Table 1. Basal area proportions between the different tree species in the mixed plots were within predetermined thresholds (given in Baeten et al., 2013) to avoid strong dominance of only one species. While plot selection was focused on dominant canopy trees, some sub-dominant woody species such as Arbutus unedo L., Fraxinus ornus L., Ilex aquifolium L., Sorbus torminalis (L.) Crantz, and others were usually admixed with the above dominant trees for not $>10 \%$ of the total basal area. In addition, a shrub layer usually $<4 \mathrm{~m}$, with ground cover of $1 \%-30 \%$, and formed by moderately shade-tolerant species such as Cornus mas L., Crataegus laevigata (Poir.) DC., Juniperus communis L., Ligustrum vulgare L., Phillyrea latifolia L. and others was present in most of the plots, as typical in thermophilous deciduous forests (Carrari et al., 2016). The tree regeneration layer over $1.3 \mathrm{~m}$ height was instead very sparse, hence not likely affecting the understorey. Environmental variables (topography, altitude and soil type, the latter inferred from local maps) were kept as constant as possible among the plots, to avoid significant covariation between the diversity gradient and environmental variables (according to the FunDivEurope plot selection protocol; Baeten et al., 2013). To sum up, plots were located at an altitude range of $250-520 \mathrm{~m}$ a.s.l., mostly on $\mathrm{N}$-facing slopes with low to average inclination $\left(5-20^{\circ}\right)$; they were all included in a sub-Mediterranean climatic area with ca. 800 $\mathrm{mm}$ of mean annual rainfall, and $12.5-13.5{ }^{\circ} \mathrm{C}$ of mean annual temperature. Bedrock was almost exclusively of siliceous nature, mainly quarzitic sandstones, and the dominant soil type was Cambisol. Using permutational analysis of variance, Carrari et al. (2016) showed no significant differences between plots in terms of site and soil conditions 


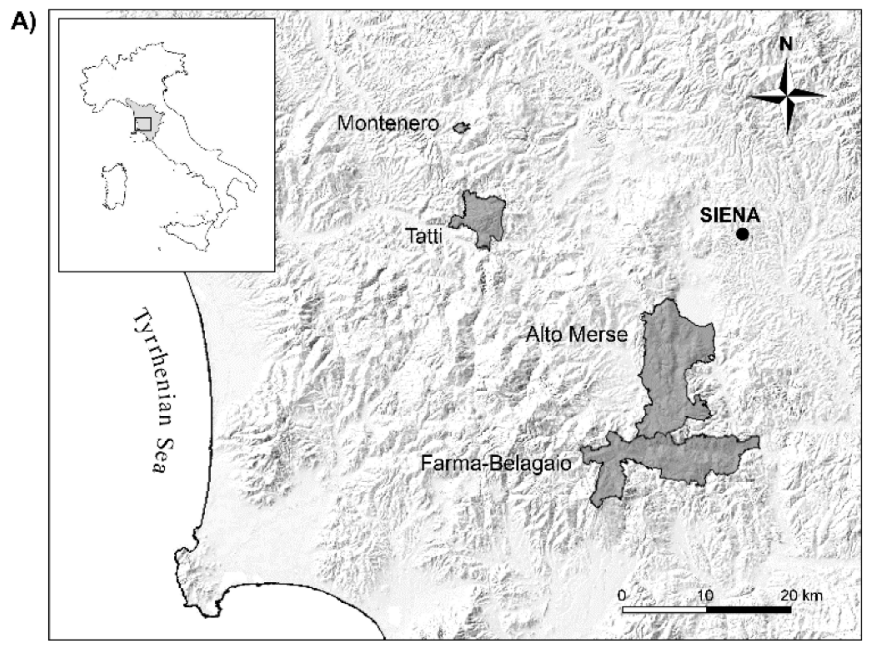

B)

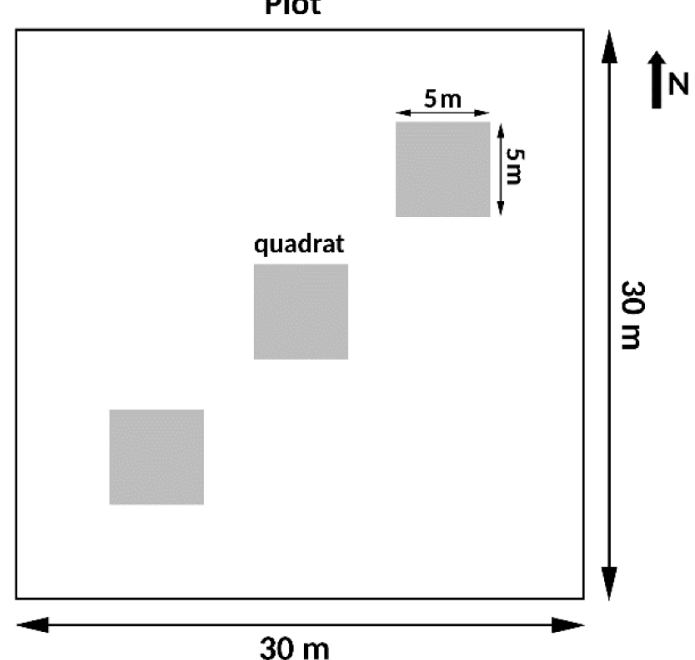

Fig. 1. (A) Study area with the forest areas where the 36 plots are localized; (B) understorey survey in three $5 \times 5 \mathrm{~m}$ quadrats within each $30 \times 30 \mathrm{~m}$ plot.

and stand structure characteristics, i.e. canopy cover and density.

Understorey data collection followed the protocol described in Ampoorter et al. (2016): in each $30 \times 30 \mathrm{~m}$ plot, three $5 \times 5 \mathrm{~m}$ sampling quadrats were placed as to minimize the edge effect and to sufficiently account for the heterogeneity of micro-topographic conditions inside the plot (Fig. 1B). In May 2012 all vascular understorey species $(<1.3 \mathrm{~m})$ in three quadrats of each plot were recorded and scored for percentage of ground cover. The same survey was carefully repeated in exactly the same spots in May 2018 under the guide of the same experienced operator (FS), allowing to limit as much as possible undesired "observer effects". The generally sparse cover and discontinuous structure of the understorey within our small quadrats also facilitated the estimation of species cover with relative precision.

Mean values of the three quadrats were used to represent the respective plot in the following analyses.

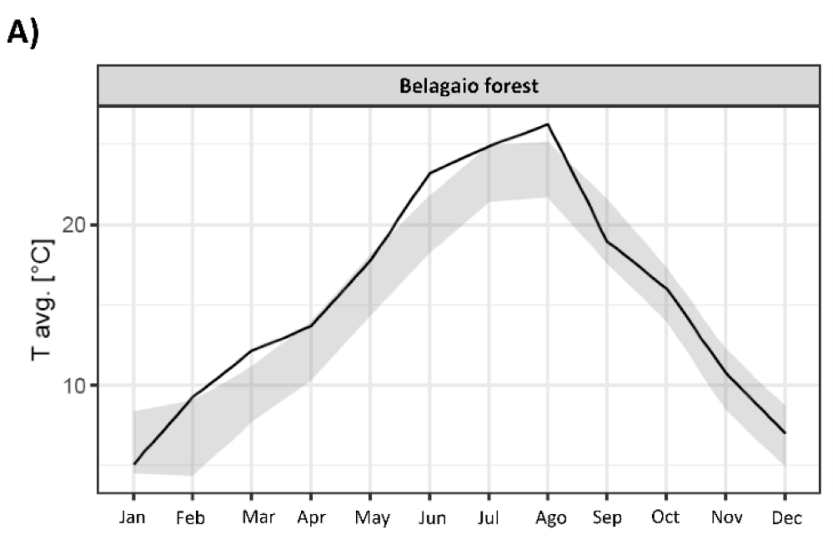

B)
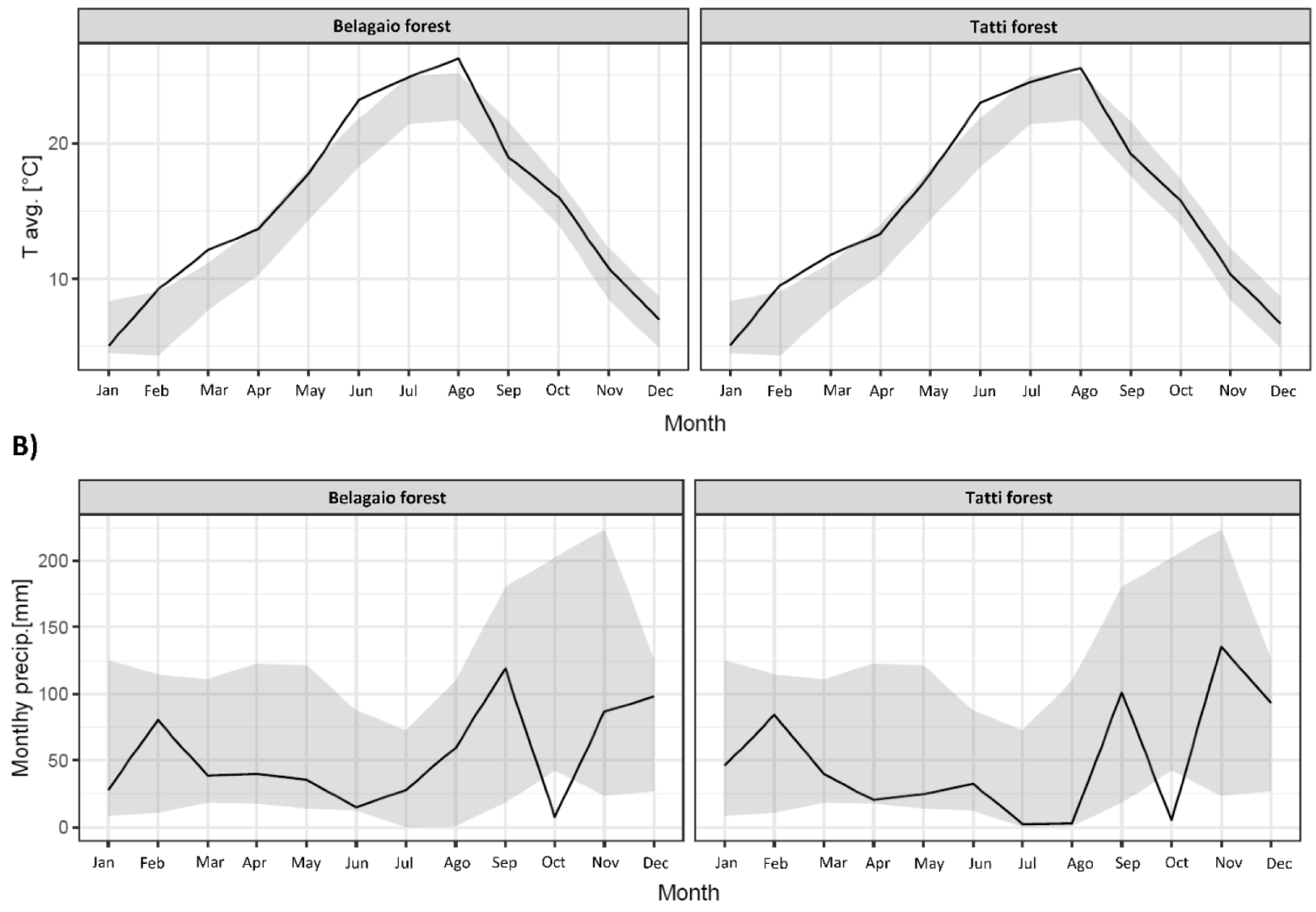

Fig. 2. (A) Average monthly temperature $\left({ }^{\circ} \mathrm{C}\right.$ ), and (B) precipitation (in cumulative $\mathrm{mm}$ ) in two sites close to the two main clusters of forest plots analyzed in this study (southern cluster: Belagaio; northern cluster: Tatti); these sites correspond to the Agri4Cast Grid no. 67,113 and 68112, respectively. Black line represents the year 2017, the grey buffer represents the average (first and last decile) of the previous 30 years. 


\subsection{The 2017 drought event, climate variables in the period 2012-2016, and other disturbances}

The year 2017 was characterized by strong decline in precipitation and soil moisture, documented by the European Space Agency (https ://phys.org/news/2017-09-italy-drought-space.html). In the study area, soil water deficit started in autumn and winter 2016 and increased in the following spring and summer, also due to unusually high temperatures (Magno et al., 2018). Fig. 2A-B show the patterns of monthly precipitation and temperatures (average and maximum) during 2017, compared with the means of the last 30 years, in two representative sites of our study area $\left(43.2^{\circ} \mathrm{N}, 11.1^{\circ} \mathrm{E}\right.$ and $43.4^{\circ} \mathrm{N}, 10.8^{\circ} \mathrm{E}$, Belagaio and Tatti forests, respectively), corresponding to the Grid no. 67,113 and 68,112 of the European Agri4Cast data portal (https://agri4cast.jrc.ec.europa. eu/dataportal/). Here, the monthly mean of maximum daily temperatures during summer (June-August) was $2.3^{\circ} \mathrm{C}$ higher in 2017 than in 2011, the year before the first vegetation survey (2012). Temperatures and precipitation in the years 2013-2016 were largely in the range of the previous 30 years, though the mean of maximum daily temperatures was higher than this range in July 2015 (Supplementary Fig. 1A) and monthly rainfall was below the lower limit of the range (Supplementary Fig. 1B). However, we assume minor impact of this short event as it occurred when the growth activity of most species in the herb-layer of thermophilous deciduous forests is already ceased. The only exceptional meteorological event recorded in Tuscany in the period 2012-2018 was the windstorm of March 4th-5th, 2015, with wind gusts over $120 \mathrm{~km} / \mathrm{h}$ especially along the Tyrrhenian coastline (Baroni et al., 2020). However, this did not have a strong impact on the forest structure in our plots, due their location far from the coast, the natural origin of the stands, their density, continuous cover (no fragmentation) and dominance of deeply rooted species such as oaks and chestnut. This resulted from the resurvey of the 36 plots in spring-summer 2017, when all trees with $\mathrm{dbh} \geq 7.5 \mathrm{~cm}$ (Baeten et al., 2013) were counted and measured separately for each species, also determining tree mortality. We found that the average proportion of basal area (BA) lost in each plot due to tree mortality after the 2015 windstorm or for other causes (both trees dead and standing or fallen to the ground) was $8.8 \% \pm 7.4$ of the $2012 \mathrm{BA}$ (min 0-max 18\%, excluding two outlier plots with $26 \%$ and $39 \%$ ). However, overall variations in total BA were not significant (paired t.test $\mathrm{p}=0.43$ ), and there were no differences between tree species richness levels $(\mathrm{p}=0.54)$. The 17 plots with $C$. sativa, however, showed higher mortality than the plots without this focal species (Benjamini \& Hochberg corrected $\mathrm{p}=0.0094$ ), caused by various weakening factors among which the severe attacks to chestnut trees by the invasive Asian gall wasp Dryocosmus kuriphilus in 2012-2015 (Guyot et al., 2015; Fernandez-Conradi et al., 2017). Nevertheless, this higher tree mortality did not result in a significant change of the plot BA in these plots (Benjamini \& Hochberg corrected $\mathrm{p}=0.055$ ), because partly compensated by the growth of the other trees.

\subsection{Data analysis}

After assessing the change in total species richness of the 36 plots between May 2012 and May 2018, we first focused on variations at the plot scale in total understorey cover, and $\alpha$ - diversity, using species richness (SR), Shannon index (H') and evenness (J).

Before analyzing understorey variations in relation to tree species richness and identity of the plots, we used Spearman rank correlation analysis $\left(r_{\mathrm{s}}\right)$ to test whether these were related to changes in total plot BA and proportion of BA lost in 2017 in each plot by tree mortality (hereafter referred to as tree mortality). This analysis was also done separately for the 17 plots with $C$. sativa, i.e. those with a significant higher proportion of BA lost by tree mortality. Also, we used Pearson productmoment correlation to test the 2012-2018 variations in cover and diversity occurred in the plots of the northern vs. the southern cluster (Tatti vs. Belagaio) in relation to temperature and precipitation.
To evaluate the effect of focal tree species richness on variations of $\alpha$-diversity, we first compared the 1-, 2-, 3- and 4-5 tree species plots and then the monospecific plots vs. the pool of mixed plots. Next, the 2012-2018 changes in understorey cover and $\alpha$-diversity were analyzed in each of the five groups of plots based on the presence of one of the five focal trees, e.g. all plots with C. sativa (17), O. carpinifolia (15), Q. cerris (19), Q. ilex (20) and Q. petraea (17; Supplementary Table 1); these are referred to as "tree species groups."

After checking for normality by using the Lilliefors (KolmogorovSmirnov) test for normality of distributions and the Bartlett test for homogeneity of variances, statistical significance of temporal changes on diversity was tested with a paired $t$-test, simple $t$-test for difference in change between richness levels and tree species groups. The resulting pvalues were not corrected for multiple comparison, being the study exploratory in nature. Moreover, in order to avoid pseudoreplication determined by the irregular spatial distribution of the sites, the influence of focal tree species richness and identity on understorey cover and diversity was tested using generalized mixed models with nested random effect of "plot" within "plot clusters", i.e. the clusters of Belagaio and Tatti areas. In a first set of models, we also included year and BA as fixed effects, including all interactions. For understorey SR (not overdispersed) the starting model was fitted with the glmer function with a Poisson error distribution and loglink, for the other variables $\left(\mathrm{H}^{\prime}, \mathrm{J}\right.$ and cover) with the lmer function with a Gaussian error distribution (lme4). The model selection of each variable followed the protocol of Zuur et al. (2009), where the structure yielding the lowest value for Akaike's information criterion (AIC; Akaike, 1973) was considered to be most consistent with the data. For models that contained random effects, a conditional $\mathrm{R}^{2}$ was calculated (Nakagawa \& Schielzeth, 2013; MuMIn package). Moreover, parameter-specific p-values for each level of the predictors were calculated using Satterthwaite approximation when models contained the random effect (lmerTest package).

Next, the 2012-2018 temporal shifts in understorey composition were determined using the Bray-Curtis distance measures based on species cover data (vegdist function in Vegan R package; Oksanen et al., 2019). Non-metric multidimensional scaling using the metaMDS function in Vegan was performed to summarize and display the compositional floristic changes of the plots, as in other studies analyzing forest vegetation shifts between two time points (Oldfield and Peterson, 2019). Differences in the magnitude of these shifts between the four levels of tree species richness and between monospecific vs. mixed plots were tested using PERMANOVA with 999 permutations (adonis function). We also tested for multivariate homogeneity of dispersion using betadisper in order to distinguish between the compositional differences determined by the level of tree species richness and the dispersion effects within each group of plots (Anderson et al., 2006; Warton et al., 2012). The same analysis was performed separately for each of the five tree species groups of plots to investigate the possible effect of overstorey tree species identity on understorey floristic changes.

At the plot scale, the 2012 and 2018 compositional changes were quantified using Sørensen $\beta$-diversity and its additive components, turnover and nestedness (Baselga, 2010). These variables were calculated for each plot to compare tree species richness levels and monospecific vs. mixed plots.

Finally, the main ecological shifts in the understorey community were analyzed by means of species Ellenberg values for the Italian flora (Pignatti et al., 2005). Mean values for light (L), temperature (T), soil humidity $(\mathrm{H})$, soil reaction $(\mathrm{R})$ and nutrients $(\mathrm{N})$ were calculated for the plots in 2012 and 2018, weighing values by species cover. Significance of the temporal shifts for each factor was determined for the four tree richness levels and the five tree species groups, as well as for monospecific vs. mixtures by the paired $t$-test. Moreover, T, L and $\mathrm{H}$ were also tested with generalized mixed models with nested random effect of "plot" within "forest areas" (lmer function with a Gaussian error distribution as explained above). All analyses were performed with $\mathrm{R}$ Studio 1.1.463 (R Core Team, 2018). 


\section{Results}

\subsection{Understorey cover}

The selected model for the variable "understorey cover" considered the nested random effect of "plot" within "plot clusters" (northern vs. southern) and included the effect of focal species richness, but not species identity. A general negative effect of monocultures compared with mixed plots was supported by this model when considering both years (Table 1). It the period 2012-2018, the mean understorey cover showed a substantial decrease from $7.2 \%$ to $3.6 \%$ ( $p<0.001$; Table 2 ). This was confirmed by model results, where the year 2018 was the main predictor with negative effect on cover (Table 1). Cover decrease was similar in monospecific vs. mixed plots, with no significant differences between tree species richness levels (Table 2). Similarly, loss of cover did not depend on the tree species identity in the overstorey, though it was more marked in the plots with the two more mesophilous tree species $Q$. petraea and O. carpinifolia (Table 2). Reduction was not related to differences in temperature and precipitation between the northern and southern plot clusters. Variations in understorey cover were not related to 2012-2017 changes in plot BA $\left(r_{\mathrm{s}}=-0.185, \mathrm{p}=\right.$ $0.278)$ and tree mortality $\left(r_{\mathrm{s}}=-80.182, \mathrm{p}=0.288\right)$; the same for the 17 C. sativa plots ( $\mathrm{p}>0.05$ for both BA changes and tree mortality).

\subsection{Diversity}

Total SR recorded in the 36 plots shifted from 109 to 115 species between 2012 and 2018 (Table 2). There was an overall positive difference between the number of newly recorded species in the 2018 survey and that of the species that were apparently missing from the first survey ( 20 vs. 14 ; Table 3 ). This increase was restricted to the monospecific plots (8:1), while there was no difference in the mixtures (13 vs. 13).

At the plot level, when considering the random effect, model results supported a negative effect of monocultures on mean SR, regardless of the year, while it excluded the effect of species identity (Table 1). Optimal model results also showed the negative effect of the year 2018 on mean SR of all plots (Table 1). Mean SR increased in monospecific plots but decreased in the mixtures, in both cases in a non-significant way (Table 2). Variations in SR were not related to 2012-2017 changes in plot BA $\left(r_{\mathrm{s}}=-0.110, \mathrm{p}=0.524\right)$ and tree mortality $\left(r_{\mathrm{s}}=\right.$ $-80.092, \mathrm{p}=0.593$ ); the same for the 17 C. sativa plots ( $\mathrm{p}>0.05$ for both BA changes and tree mortality).

Overall, the average Shannon Index increased from 2012 to 2018 (p

\section{Table 1}

Optimal mixed effects model structures relating the response variables (understorey cover, Species Richness-SR, Shannon Index-H' and Evenness-J, L and T Ellenberg values) to the year and plot type $[R$ syntax: $y \sim$ focal tree species richness + year + (1 | Plot clusters/plot id)]. Values for the predictor variables, focal tree species richness (level: monocultures and mixed forests) and year (levels: 2012 and 2018) and are parameter estimates (SE). $\mathrm{R}^{2}$ refers to the fraction of variation explained by the optimal model structure. Significance level: ${ }^{*} \mathrm{p}<0.05,{ }^{* *}<\mathrm{p}<0.01,{ }^{* * *} \mathrm{p}<0.001$.

\begin{tabular}{llllll}
\hline & Cover & SR & H' & J & L \\
\hline $\begin{array}{l}\text { Monocultures (both } \\
\text { years) }\end{array}$ & -0.17 & -0.136 & & & $0.546^{* * *}$ \\
& & & & & \\
Year 2018 (all plots) & $(0.318)$ & $(0.126)$ & & & $(0.277)$ \\
& $-0.12^{* * *}$ & $-0.011^{* * *}$ & $0.033^{* * *}$ & $0.014^{* * * *}$ & \\
Constant & $(0.018)$ & $(0.001)$ & $(0.013)$ & $(0.004)$ & \\
& $258.5^{* \ldots *}$ & $25.6^{* * *}$ & $-65.0^{* * *}$ & $-27.6^{* * *}$ & $4.1^{* \ldots *}$ \\
Observations & $(36.6)$ & $(1.2)$ & $(26.1)$ & $(9.0)$ & $(0.2)$ \\
Log Likelihood & 72 & 72 & 72 & 72 & 72 \\
Akaike Inf. Crit. & -84.19 & -219.54 & -49.16 & 26.29 & -73.57 \\
Bayesian Inf. Crit. & 180.38 & 449.07 & 108.31 & -42.59 & 157.14 \\
$\mathrm{R}^{2}$ & 194.04 & 460.46 & 119.69 & -31.20 & 168.52 \\
\hline
\end{tabular}

$=0.015$; Table 2), as confirmed by model results (Table 2), and this was especially in the monospecific plots ( $p<0.01$; Table 2$)$. The parallel increase in evenness ( $\mathrm{p}<0.05$; Tables 1,2$)$ was mainly driven by a ground cover reduction of juvenile tree species such as $Q$. ilex $(-1.2 \%)$, F. ornus $(-0.8 \%)$ and others, as well as shrubs species such as Juniperus communis (-83.3\%) and Erica scoparia (-0.3\%; Fig. 3A). Diversity changes in the mixtures were negligible; no effect on evenness was recorded here because ground cover reduction of tree species was minor (Fig. 3B). The optimal model excluded the effect of species richness and identity for $\mathrm{H}^{\prime}$ and $\mathrm{J}$ (Table 1 ). Variations in $\mathrm{H}^{\prime}$ were not related to $2012-2017$ changes in plot BA $\left(r_{\mathrm{s}}=-0.051, \mathrm{p}=0.846\right)$ and tree mortality $\left(r_{\mathrm{s}}=-0.046, \mathrm{p}=0.788\right)$; the same for the 17 C. sativa plots ( $\mathrm{p}>$ 0.05 for both BA changes and tree mortality).

In each case, species diversity indexes were not related to variations of temperature and precipitation between the two clusters (Tatti and Belagaio).

The five tree species-based groups of plots showed minor variations in overall species richness between 2012 and 2018. At the plot level, there was a decrease in mean species richness and increase in Shannon index driven by an increase of evenness (Table 2).

\subsection{Compositional changes}

Overall, $86 \%$ of the species that were recorded in 2012 were also found in 2018. Among the missing taxa in the second survey there were perennial herbs and shrubs, while the newly found taxa included synanthropic annual weeds (genera Erigeron, Senecio, Sonchus), perennial graminoids, herbs and xerophilous woody shrubs, mainly occurring as seedlings (Supplementary Table 2). Noteworthy, most of these newly appeared species were only in the monospecific plots. Frequency of the species only present in 2012 or 2018 was very low, regardless of the treespecies richness level (Supplementary Table 2).

Sørensen $\beta$-diversity did not differ between the four levels of tree species richness suggesting negligible effects on the 2012-2018 understorey compositional shifts. Large variability occurred especially in the monospecific plots. In the mixed stands, understorey species turnover tended to decrease along the tree richness gradient $(\mathrm{p}<0.05$ between the 2 -species plots and $4 / 5$ species plots), while nestedness showed an opposite trend.

The final run of the NMDS on the whole set of 36 plots (Fig. 4A) had a stress of $0.20\left(\mathrm{R}^{2}\right.$ linear fit $=0.824$; non-metric fit $\left.\mathrm{R}^{2}=0.958\right)$ and showed an overall significant shift mainly along the second axis $\left(\mathrm{p}_{\mathrm{perm}}\right.$ $=0.001$ ). Magnitude of the shift was variable among the plots with the different tree species, being non-significant for the $Q$. cerris and $Q$. ilex plots and significant for the Q. petraea, C. sativa and O. carpinifolia plots (Fig. 3B-F).

Direction of the significant shifts was variable depending on tree species. The $C$. sativa plots prevalently moved along axis 2 and towards the positive part of axis 1 , due to a general sharp decrease in the species cover and a reduction or even disappearance of chestnut seedlings. Plots with $Q$. petraea shifted along the 2 nd axis towards positive values while those with $O$. carpinifolia moved towards the negative part of the 1 st axis, in both cases reflecting a reduction of understorey species cover.

When analyzing monospecific and mixed plots separately, the stress was 0.12 for the former $\left(R^{2}\right.$ linear fit $=0.942$; non-metric fit $\left.R^{2}=0.985\right)$ and 0.22 for the mixtures $\left(\mathrm{R}^{2}\right.$ linear fit $=0.749$; non- metric fit $\mathrm{R}^{2}=$ 0.951). The non-significant downward shift of monospecific plots along axis 2 reflected a cover reduction, while the minor shift to the right was due to the entry of a greater number of new species in 2018 (Fig. 5A). The slight shift of mixed plots towards positive values of axis 1 resulted significant, and again due a general trend of cover reduction of the understorey species (Fig. 5B; $\mathrm{p}_{\text {perm }}=0.002$ ).

\subsection{Ellenberg values}

Temporal (2012-2018) variations in mean cover-weighted Ellenberg 
Table 2

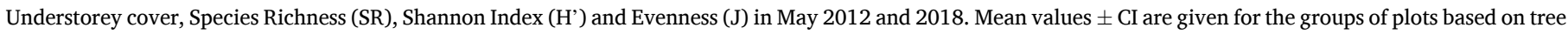
species richness and focal tree species (significance level: ${ }^{*} \mathrm{p}<0.05,{ }^{* *}<\mathrm{p}<0.01,{ }^{* * *} \mathrm{p}<0.001$ ).

\begin{tabular}{|c|c|c|c|c|c|c|c|c|c|c|c|c|c|c|}
\hline & \multicolumn{3}{|l|}{ Cover \% } & \multicolumn{3}{|l|}{ SR } & \multicolumn{3}{|l|}{$\mathrm{H}^{\prime}$} & \multicolumn{3}{|l|}{$\mathrm{J}$} & \multicolumn{2}{|c|}{ Total SR } \\
\hline & 2012 & 2018 & $\mathrm{p}$ & 2012 & 2018 & $\mathrm{p}$ & 2012 & 2018 & $\mathrm{p}$ & 2012 & 2018 & $\mathrm{p}$ & 2012 & 2018 \\
\hline \multicolumn{15}{|l|}{$\begin{array}{l}\text { Tree species richness } \\
\text { level }\end{array}$} \\
\hline Monocultures & $5.4 \pm 4.6$ & $\begin{array}{l}2.3 \pm \\
0.9\end{array}$ & & $\begin{array}{l}15.8 \pm \\
5.5\end{array}$ & $\begin{array}{l}17.0 \pm \\
4.6\end{array}$ & & $\begin{array}{l}1.72 \pm \\
0.27\end{array}$ & $\begin{array}{l}2.23 \pm \\
0.15\end{array}$ & $* *$ & $\begin{array}{l}0.68 \pm \\
0.11\end{array}$ & $\begin{array}{l}0.90 \pm \\
0.16\end{array}$ & * & 60 & 74 \\
\hline 2- sp. mixtures & $9.3 \pm 7.3$ & $\begin{array}{l}5.7 \pm \\
6.3\end{array}$ & & $\begin{array}{l}21.4 \pm \\
3.5\end{array}$ & $\begin{array}{l}20.2 \pm \\
3.5\end{array}$ & & $\begin{array}{l}1.92 \pm \\
0.30\end{array}$ & $\begin{array}{l}2.08 \pm \\
0.47\end{array}$ & & $\begin{array}{l}0.63 \pm \\
0.09\end{array}$ & $\begin{array}{l}0.68 \pm \\
0.14\end{array}$ & & 81 & 80 \\
\hline 3- sp. mixtures & $6.8 \pm 2.3$ & $\begin{array}{l}3.4 \pm \\
0.3\end{array}$ & * & $\begin{array}{l}20.8 \pm \\
4.1\end{array}$ & $\begin{array}{l}18.1 \pm \\
3.9\end{array}$ & & $\begin{array}{l}1.92 \pm \\
0.29\end{array}$ & $\begin{array}{l}1.88 \pm \\
0.28\end{array}$ & & $\begin{array}{l}0.64 \pm \\
0.07\end{array}$ & $\begin{array}{l}0.63 \pm \\
0.09\end{array}$ & & 81 & 67 \\
\hline 4/5-sp. mixtures & $6.9 \pm 3.4$ & $\begin{array}{l}2.6 \pm \\
1.7\end{array}$ & & $\begin{array}{l}16.3 \pm \\
3.5\end{array}$ & $\begin{array}{l}13.9 \pm \\
2.9\end{array}$ & & $\begin{array}{l}1.67 \pm \\
0.32\end{array}$ & $\begin{array}{l}1.84 \pm \\
0.82\end{array}$ & & $\begin{array}{l}0.61 \pm \\
0.11\end{array}$ & $\begin{array}{l}0.69 \pm \\
0.17\end{array}$ & & 46 & 44 \\
\hline Subtotal mixed plots & $7.8 \pm 2.9$ & $\begin{array}{l}4.0 \pm \\
2.4\end{array}$ & & $\begin{array}{l}19.7 \pm \\
2.2\end{array}$ & $\begin{array}{l}17.6 \pm \\
2.2\end{array}$ & & $\begin{array}{l}1.85 \pm \\
0.17\end{array}$ & $\begin{array}{l}1.94 \pm \\
0.23\end{array}$ & & $\begin{array}{l}0.63 \pm \\
0.05\end{array}$ & $\begin{array}{l}0.66 \pm \\
0.08\end{array}$ & & 104 & 100 \\
\hline \multicolumn{15}{|l|}{$\begin{array}{l}\text { Focal tree species } \\
\text { groups }\end{array}$} \\
\hline C. sativa & $4.8 \pm 1.2$ & $\begin{array}{l}2.2 \pm \\
0.7\end{array}$ & $* * *$ & $\begin{array}{l}17.8 \pm \\
2.6\end{array}$ & $\begin{array}{l}15.8 \pm \\
2.8\end{array}$ & & $\begin{array}{l}1.88 \pm \\
0.27\end{array}$ & $\begin{array}{l}2.03 \pm \\
0.24\end{array}$ & & $\begin{array}{l}0.66 \pm \\
0.07\end{array}$ & $\begin{array}{l}0.75 \pm \\
0.08\end{array}$ & & 73 & 68 \\
\hline O. carpinifolia & $\begin{array}{l}10.0 \pm \\
5.4\end{array}$ & $\begin{array}{l}5.1 \pm \\
4.6\end{array}$ & $* * *$ & $\begin{array}{l}19.7 \pm \\
3.8\end{array}$ & $\begin{array}{l}17.9 \pm \\
3.5\end{array}$ & & $\begin{array}{l}1.82 \pm \\
0.23\end{array}$ & $\begin{array}{l}1.91 \pm \\
0.35\end{array}$ & & $\begin{array}{l}0.62 \pm \\
0.07\end{array}$ & $\begin{array}{l}0.68 \pm \\
0.13\end{array}$ & & 85 & 81 \\
\hline Q. cerris & $6.4 \pm 1.9$ & $\begin{array}{l}3.0 \pm \\
1.0\end{array}$ & $* * *$ & $\begin{array}{l}20.0 \pm \\
3.1\end{array}$ & $\begin{array}{l}17.5 \pm \\
2.7\end{array}$ & & $\begin{array}{l}1.87 \pm \\
0.20\end{array}$ & $\begin{array}{l}1.99 \pm \\
0.25\end{array}$ & & $\begin{array}{l}0.64 \pm \\
0.06\end{array}$ & $\begin{array}{l}0.71 \pm \\
0.09\end{array}$ & & 90 & 91 \\
\hline Q. ilex & $7.3 \pm 4.0$ & $\begin{array}{l}4.0 \pm \\
3.3\end{array}$ & $* * *$ & $\begin{array}{l}17.2 \pm \\
2.9\end{array}$ & $\begin{array}{l}16.0 \pm \\
2.7\end{array}$ & & $\begin{array}{l}1.72 \pm \\
0.19\end{array}$ & $\begin{array}{l}1.92 \pm \\
0.27\end{array}$ & & $\begin{array}{l}0.63 \pm \\
0.06\end{array}$ & $0.72 \pm 0.1$ & & 90 & 89 \\
\hline Q. petraea & $8.1 \pm 2.8$ & $\begin{array}{l}3.4 \pm \\
1.1\end{array}$ & $* * *$ & $\begin{array}{l}19.2 \pm \\
3.0\end{array}$ & $\begin{array}{l}17.8 \pm \\
2.9\end{array}$ & & $\begin{array}{l}1.74 \pm \\
0.24\end{array}$ & $\begin{array}{l}1.88 \pm \\
0.29\end{array}$ & & $\begin{array}{l}0.59 \pm \\
0.07\end{array}$ & $0.67 \pm 0.1$ & & 73 & 73 \\
\hline Total of 36 plots & $7.2 \pm 2.5$ & $\begin{array}{l}3.6 \pm \\
1.8\end{array}$ & $* * *$ & $\begin{array}{l}18.7 \pm \\
2.2\end{array}$ & $\begin{array}{l}17.5 \pm \\
2.0\end{array}$ & & $\begin{array}{l}1.82 \pm \\
0.15\end{array}$ & $\begin{array}{l}2.01 \pm \\
0.18\end{array}$ & * & $\begin{array}{l}0.64 \pm \\
0.05\end{array}$ & $\begin{array}{l}0.72 \pm \\
0.08\end{array}$ & $* *$ & 109 & 115 \\
\hline
\end{tabular}

\section{Table 3}

Number of understorey species only recorded in the first (2012) and second survey (2018) in the four tree species richness levels, and in the five groups of plots based on presence of focal tree species, with relative variation $(\Delta)$.

\begin{tabular}{llll}
\hline & Only recorded in 2012 & Only recorded in 2018 & $\Delta$ \\
\hline Monospecific & 1 & 8 & +7 \\
2-sp mixtures & 7 & 9 & +2 \\
3-sp mixtures & 7 & 4 & -3 \\
4/5 sp mixtures & 0 & 2 & +2 \\
Mixed plots & 13 & 13 & 0 \\
Castanea sativa & 4 & 5 & +1 \\
Ostrya carpinifolia & 9 & 14 & +5 \\
Quercus cerris & 10 & 12 & +2 \\
Quercus ilex & 10 & 13 & +3 \\
Quercus petraea & 5 & 4 & -1 \\
Total & 14 & 20 & +6 \\
\hline
\end{tabular}

values of the 36 plots resulted minor for all factors. Shifts in the position of the plots in the bi-dimensional L-H and L-T space were of variable magnitude on the two axes, but directionally not consistent for monocultures and mixtures (Fig. 6A, B). No differences were found along the tree richness gradient, nor between the five tree species groups of plots. The direction of change of the light value, however, was marginally significant and positive in the monospecific stands but mainly negative in the mixed ones, particularly in the 3- and 4-species mixtures. Model results supported a higher $L$ value in the monocultures, regardless of the year (Table 1).

\section{Discussion}

Although numerous studies have shown the multiple effects of global change on the diversity and composition of the understorey vegetation in temperate forests (reviewed in Landuyt et al., 2019), the impacts of extreme drought and heat events are still unknown. Practical difficulties in experimentally simulating such episodes and in separating the effects of drought and heat from those of other possible disturbance factors on the stands are likely the main reasons for the current lack of studies on this topic. Re-surveying the understorey of permanent forest plots at different time points after these events, while accounting for other disturbances, is one possible approach to advance our understanding of the direct effects. The present study goes in this direction by describing the changes in the understorey of thermophilous deciduous forests about one year after the 2016-2017 drought crisis in S Europe, while considering the possible effects of other non-anthropogenic disturbances.

A first notable finding was the $50 \%$ decrease in total ground cover in 2018, with no differences between monospecific and mixed plots. Among the other potential causes that could be expected for this decline, next to drought, is a possible reduction of light availability at the forest floor driven by increased cover by dominant trees along the natural forest dynamics. Understorey abundance and productivity in temperate forests is in fact primarily controlled by light, which is in turn regulated by canopy characteristics (Barbier et al., 2008; Axmanová et al., 2011; Tinya et al., 2016). However, measurement of the 2012-2018 variations in BA of our 36 plots showed no increase in the stands also due to tree mortality during the 2015 windstorm and the spread of the Asian chestnut gall wasp (see Material and Methods). Moreover, the potential effects of these disturbances on understorey abundance would have been positive rather than negative, since tree mortality and increased crown transparency can only increase light availability at the forest floor. This, coupled with the lack of relation between BA and understorey cover variations in our plots, provides circumstantial support that understorey decline was mostly driven by the 2016-2017 drought. This finding is in line with the strong reduction of ground vegetation cover observed in a pine forest after three years of drought (Ozolinčius et al. 2009), and with evidence that abundance of many forest species decreases soon after drought events, with negative consequences on overall ecosystem productivity (Archaux and Wolters, 2006). In the study by Ozolinčius et al. (2009), loss of ground cover was associated with a $20 \%$ decrease in also the Shannon index, while we found that the negative impact was on plot species richness but not on Shannon-diversity. These results support Felsmann et al. (2018) who found a tendency for lower species richness vs. considerable stability in the structure (diversity and composition) of understorey community of beech and conifer forests exposed to drought 
A

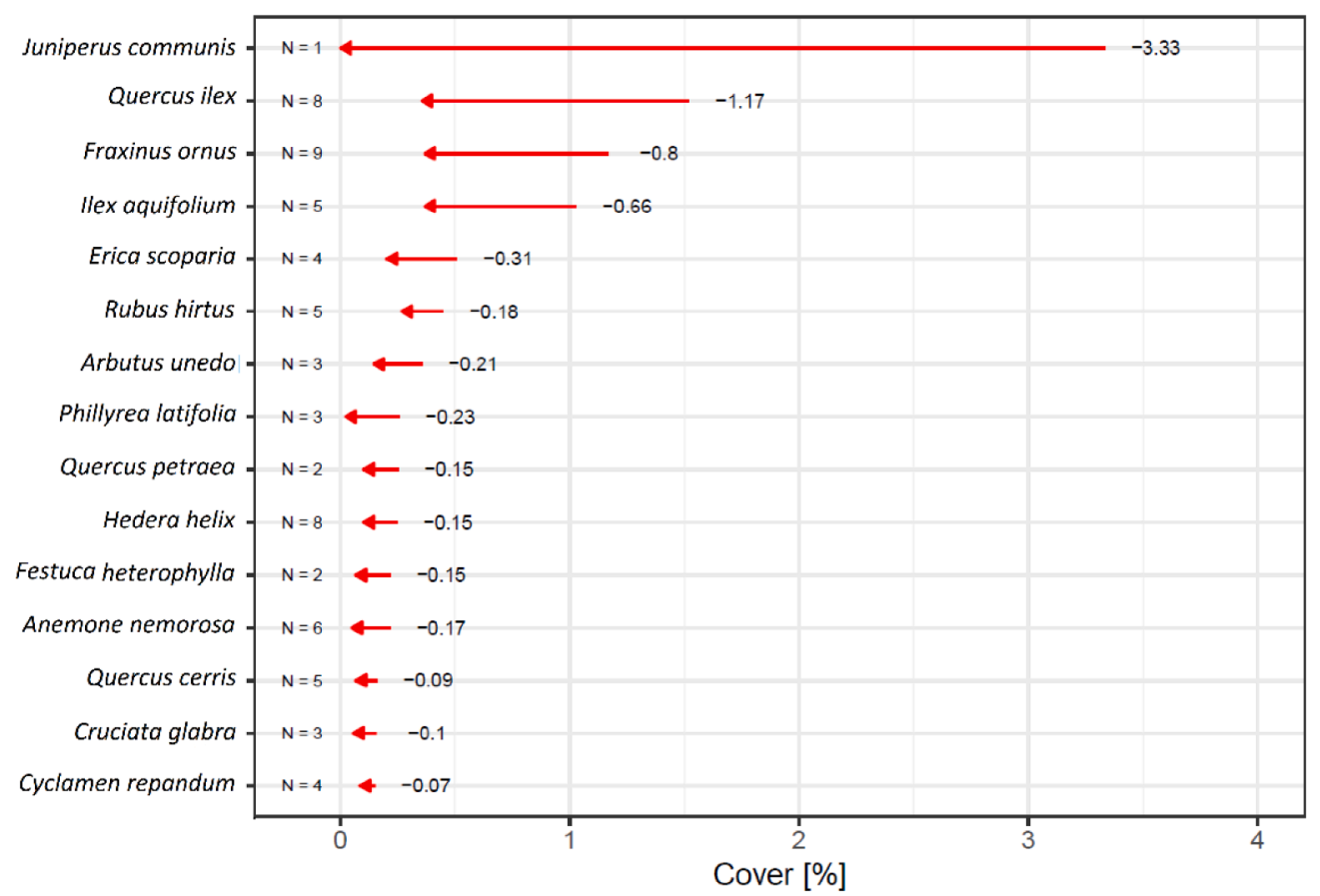

B

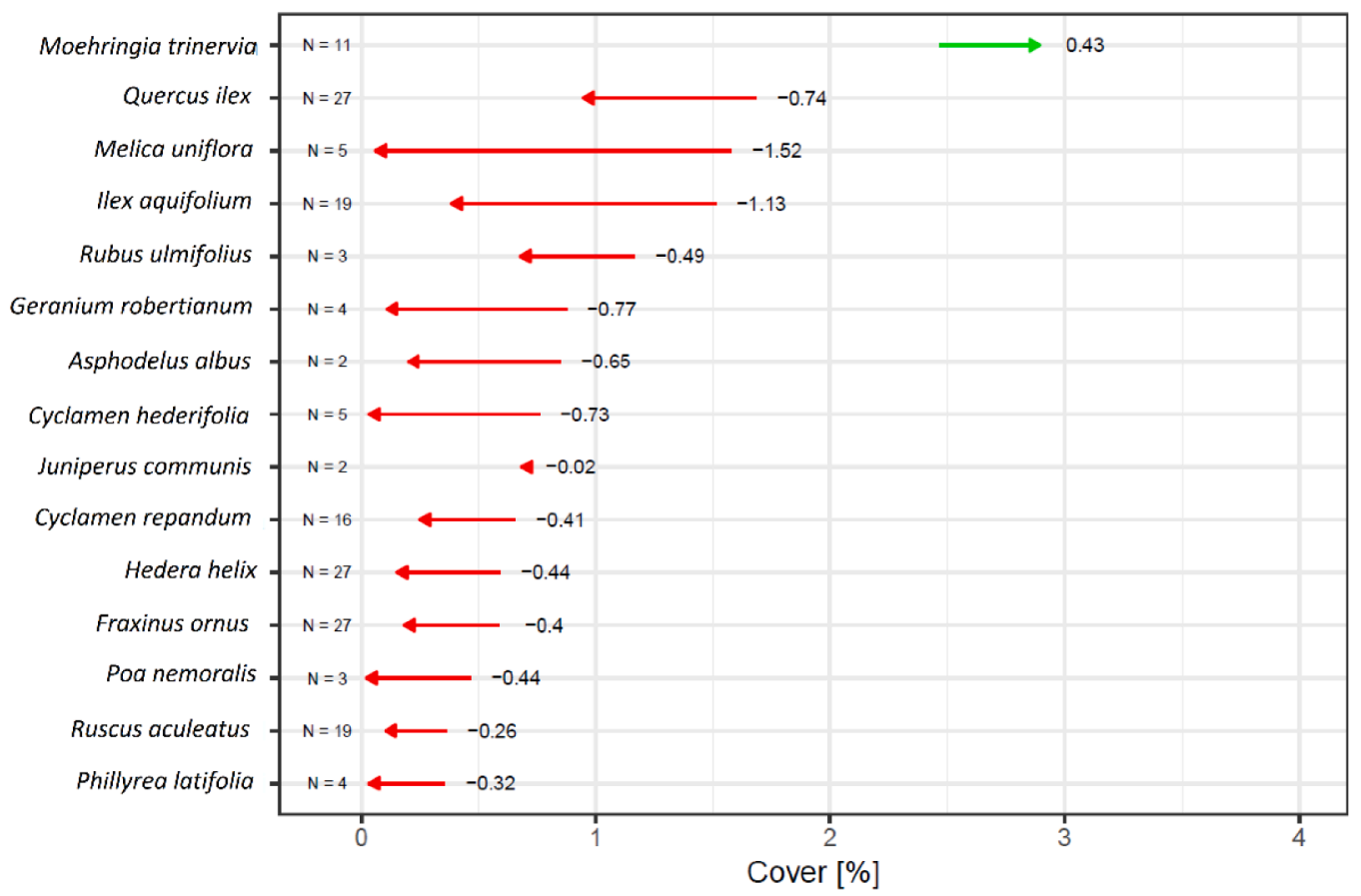

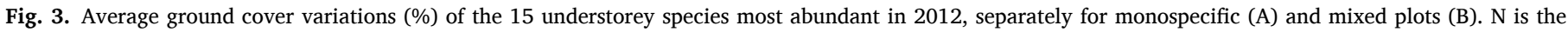

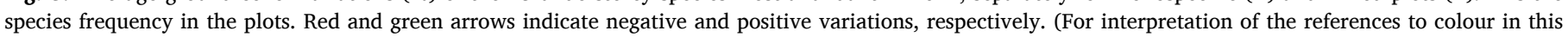
figure legend, the reader is referred to the web version of this article.)

treatments for 18 months. In that experiment diversity was not affected thanks to the high plasticity of understorey plants to moderate reduction of soil water content (Felsmann et al., 2018). Considerable stability of forest understorey communities and factors influencing species resistance to drought have been also reported by Archaux and Wolters (2006). In the present study the overall increase of plot Shannon diversity was not associated with variations in plot tree mortality or BA variations between 2012 and 2017 and was determined by a higher species evenness in the monocultures. The latter was consequent to the balancing of cover proportions between understorey species, a kind of response to external disturbances already observed in forests of the same region (Selvi et al., 2016). In our case, the balancing of cover proportion resulted from a decreased abundance of tree regeneration (mainly F. ornus, $Q$. ilex, $Q$. cerris and $Q$. petraea), which supports the lower adaptation of temperate forest tree seedlings to drought and thus their higher vulnerability to stress with respect to herbaceous understorey 
A)

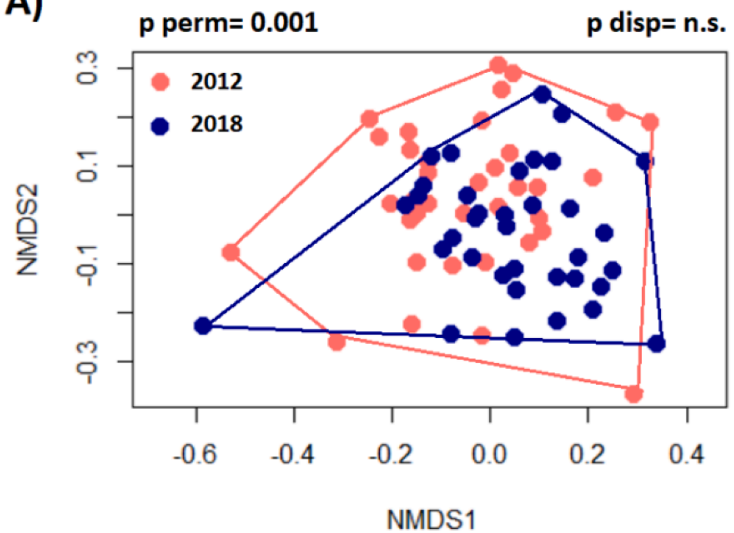

C)

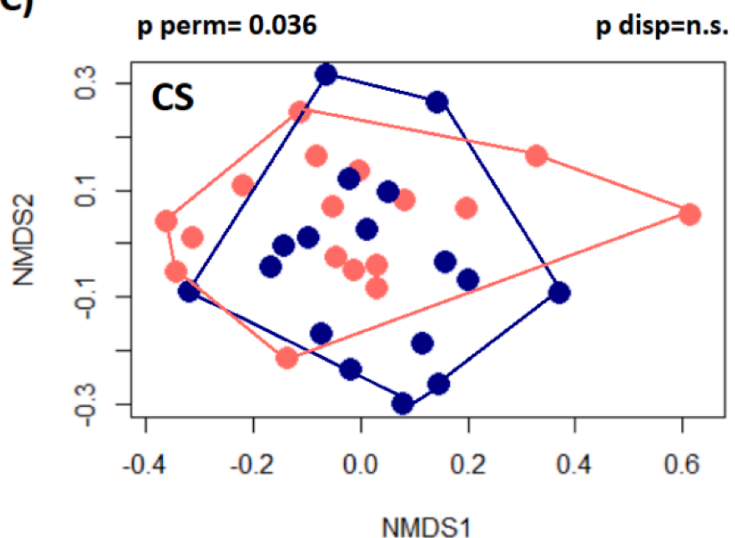

E)

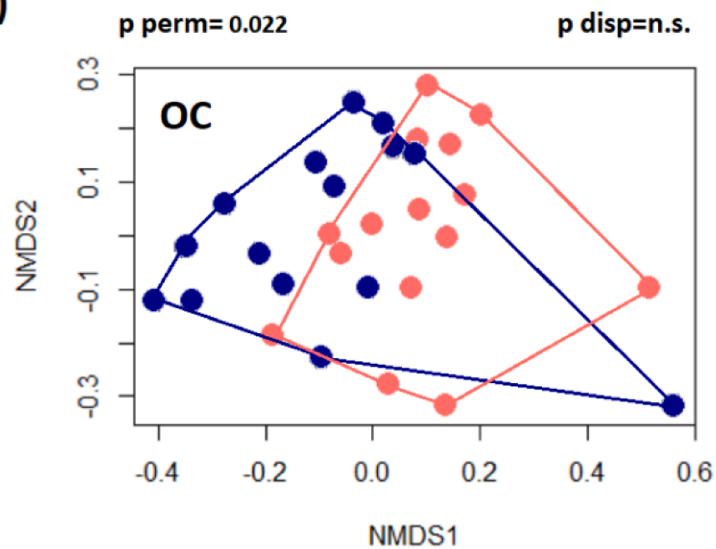

B)

p perm $=$ n.s. p disp=n.s

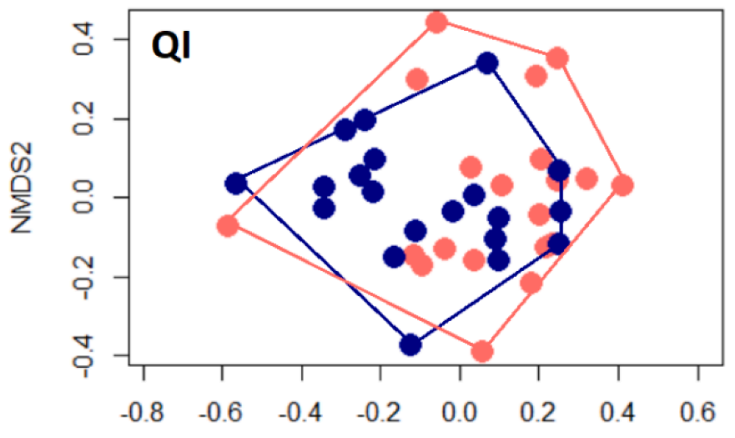

NMDS1

D)

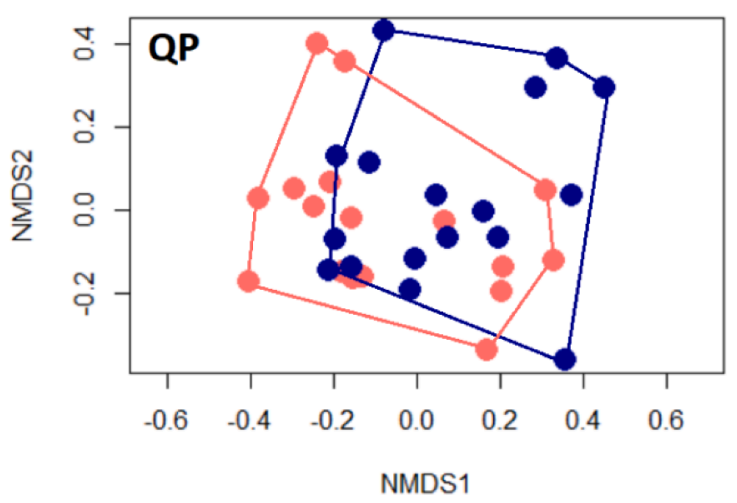

F)

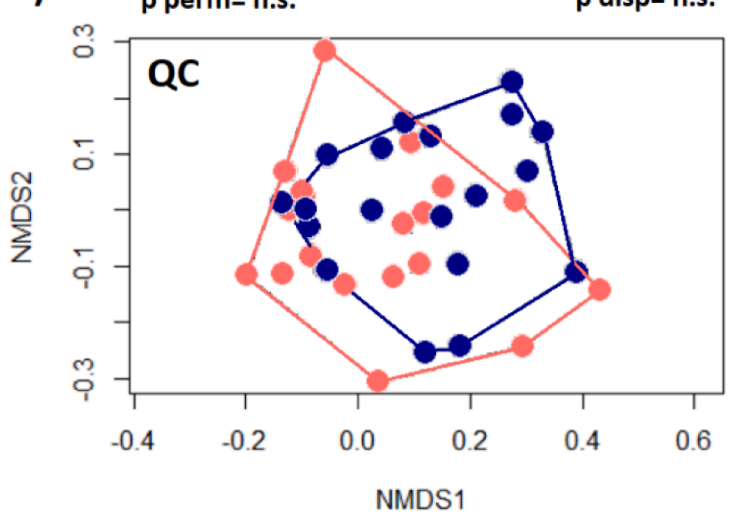

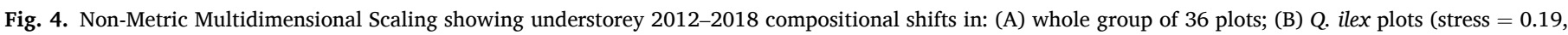

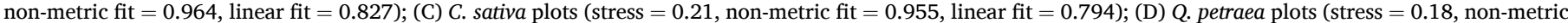

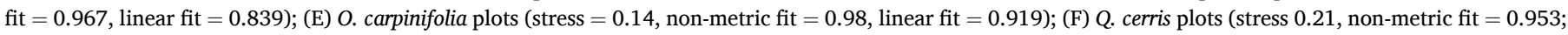

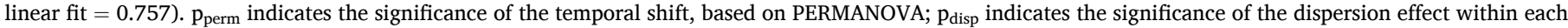
group of plots (e.g. year)

species (Berkowitz et al., 1995; Putnam and Reich, 2017). This negative effect on tree regeneration abundance also supports that drought in 2017 was a major driving factor of both understorey evenness increase and ground cover decrease, since trees in our plots were much less able than annual and perennial herbaceous species to quickly recover from autumn 2017 to early spring 2018 (e.g. just before the second survey). Based on data from the (Tuscan Regional Hydrological and Geological Service (https://www.sir.toscana.it/), the amount of rainfall from January to May 2018 was in the mean of the previous 12 years in both forest areas, which have likely allowed a partial recovery of at least part of the herbaceous flora.

However, decline in tree regeneration strongly characterized the monospecific plots, supporting evidence that tree species mixing in the overstorey frequently improves resource supply and tree resistance to drought by mechanisms like niche complementarity and interspecific facilitation (Morin et al., 2011; Pretsch, 2013). For example, Pretsch et al. (2012) observed that water stress release in beech is facilitated when mixed to oak thanks to a hydraulic lift of water by the root system of the latter species. Moreover, there is evidence that the benefit of species mixing on tree growth, like for other ecosystem functions, is 
A)

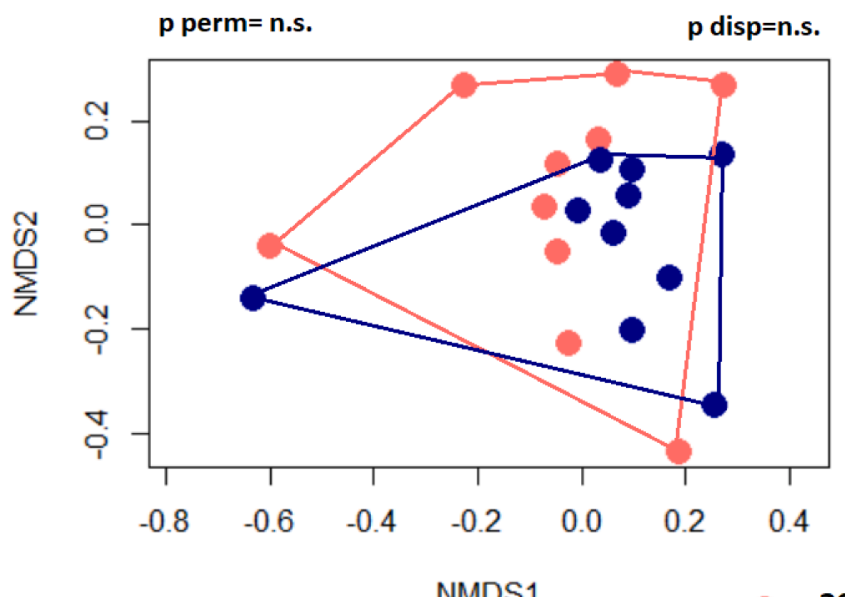

B)

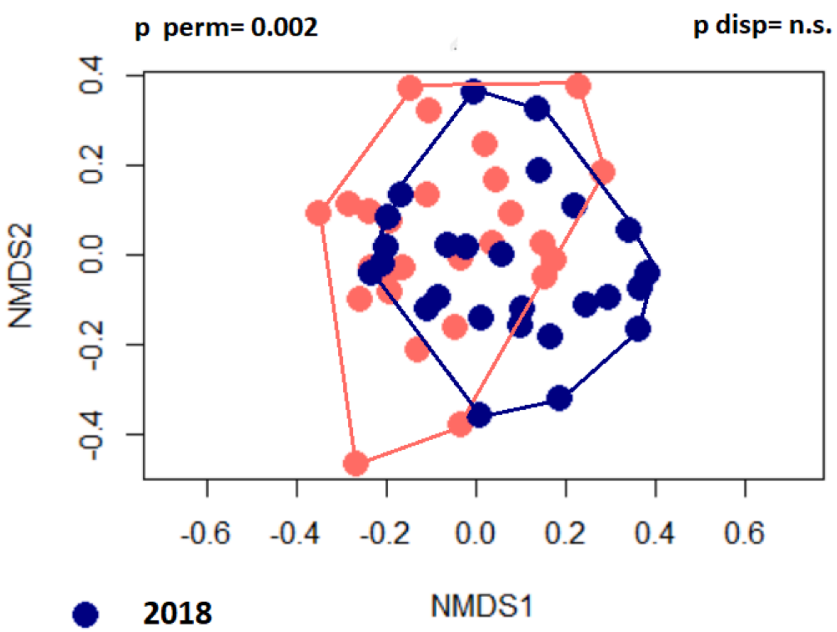

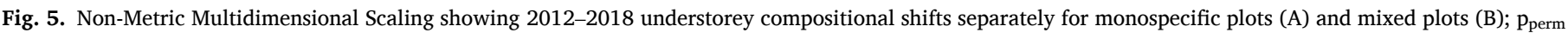

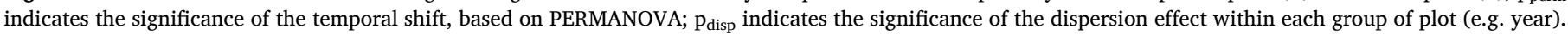

A)

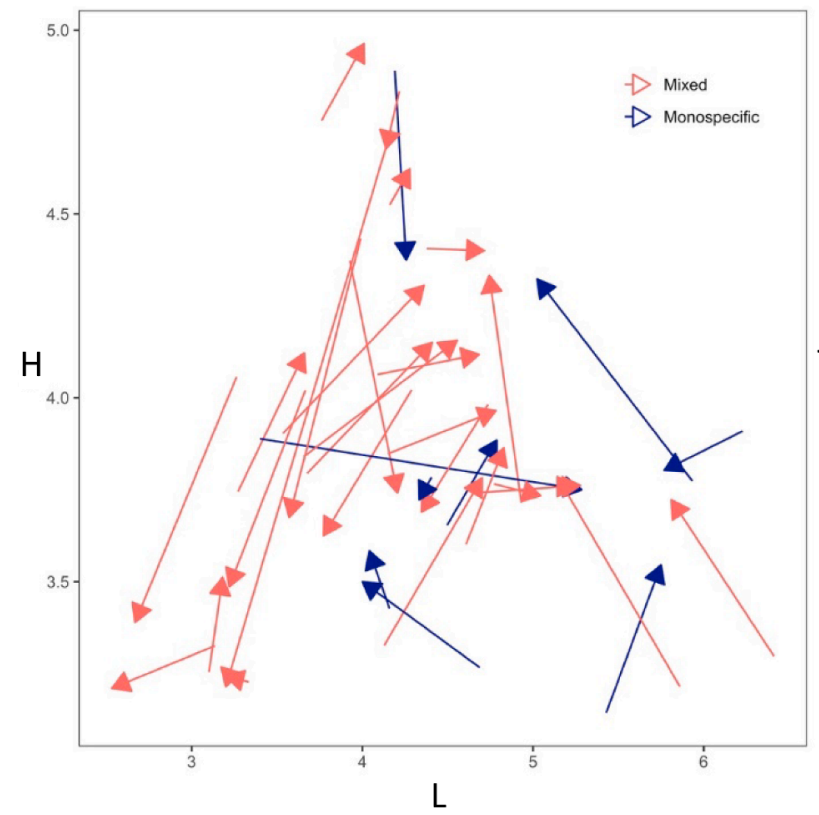

B)

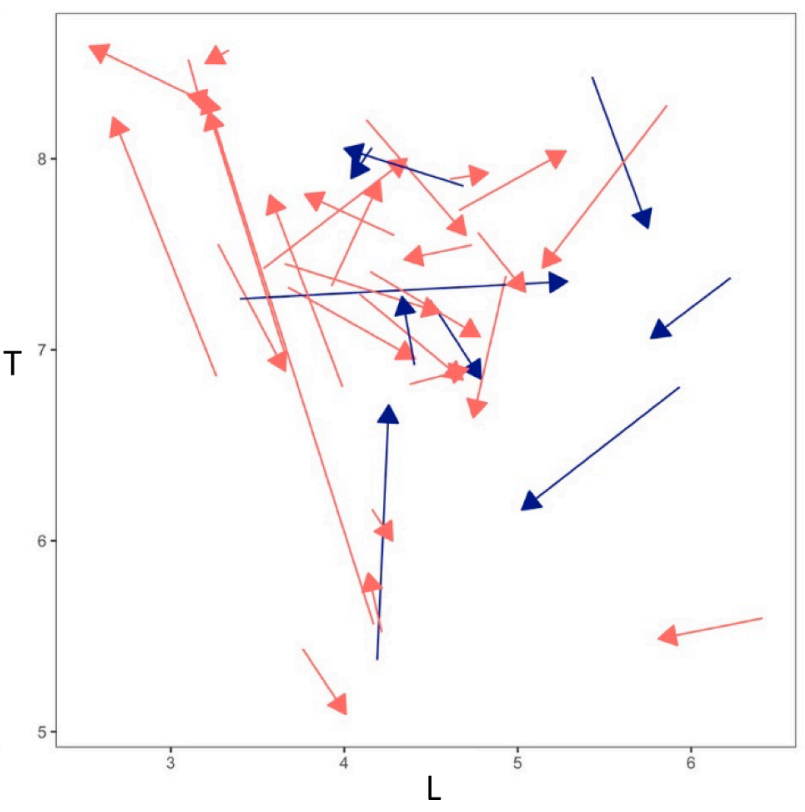

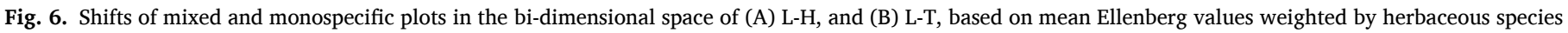
cover. Arrows show the direction of the shift from 2012 to 2018.

more pronounced in forests of water-limited regions such as that of the present case study (Pretsch, 2013; Ratcliffe et al., 2017).

In terms of understorey species composition, temporal $\beta$-diversity analysis showed relatively minor shifts, as observed in French forests after the extreme 2003 drought event (Archaux and Wolters, 2006). Shifts occurred in the same direction in monospecific and mixed stands, though only in the latter these were significant due to cover variations and to, a lesser extent, species turnover. Changes were of different magnitude also depending on the focal tree species present in the overstorey, being smaller and not significant in the plots with the two more southern and drought-adapted species (either Q. ilex or Q. cerris) than in those with one of the three more mesophilous species (O. carpinifolia, C. sativa and Q. petraea; Coppi et al., 2019). While suggesting a possible tree species identity effect, this finding supports higher tolerance to water stress in understorey species of lowland mediterranean and sub-mediterranean woodlands, compared with those of more mesic forests at more northern latitudes or higher altitudes, as a result of the multiple drought adaptive traits of Mediterranean forest plants (Nardini et al., 2014).

Compositional shifts translated into only minor changes in mean Ellenberg values of the plots also due to a substantial ecological equivalence between the species gained or lost between the two surveys. While changes of plot position in the L-H and L-T space did not show consistent differences between monospecific and mixed plots, the former group showed an increase of light value due to the entry of annual species of mainly open habitats that was not observed in the mixtures.

Due to the short time between the 2017 event and our re-survey, this 
study evaluated understorey resistance to drought but not its resilience. However, the impact of intense drought episodes may appear primarily during a prolonged recovery phase rather than during or shortly after the event itself (see Gutschick et al., 2003). Moreover, resistance and resilience to drought may be negatively linked in herbaceous plant communities, depending on species traits and competitive interactions (McGillivray et al., 1995). Hence, assessing the impact of such events would require to monitor changes over a longer period through a system of permanent plots, as well as a better understanding of the various means and adaptive strategies that may allow recovery in the long-term.

\section{Conclusions}

This study suggests that intense drought events may affect species abundance and diversity of the understorey of thermophilous deciduous forests in S Europe. On the other hand, the small directional changes in floristic composition pointed to elevated drought resistance of the herblayer species. Our findings also support different responses in monospecific versus mixed stands. Monocultures showed an increase in species diversity driven by two mechanisms that may not be favorable for the integrity and persistence of the forest communities, i.e. a more marked decrease in abundance of juvenile woody species and the appearance of non-forest specialists such as synanthropic weeds and non-native species. These two mechanisms had a lower incidence in the mixed stands, suggesting a higher diversity stability after drought episodes. Hence, favoring overstorey species mixing that results from the natural dynamics of these forests is likely the right management strategy to attenuate the effects of extreme events. Evidence for the above effects is circumstantial, as understorey differences between the two survey years are likely to combine processes that could not be entirely accounted for in this study, such as stochastic year-to-year species turnover, trends due to forest aging and short-term disturbances. More studies and monitoring programs are therefore needed to understand changes and resilience of the understorey vegetation in the long-term.

\section{Funding}

This work was supported by funds from the EU project SoilForEUROPE involving FB and FS and a grant to GI from the Research Doctorate in Agricultural and Environmental Sciences, XXXII cycle, University of Firenze, Italy.

\section{CRediT authorship contribution statement}

Giovanni Iacopetti: Data curation, Investigation, Writing - original draft. Filippo Bussotti: Supervision. Elisa Carrari: Data curation, Writing - review \& editing. Sofia Martini: Data curation. Federico Selvi: Conceptualization, Methodology, Writing - review \& editing, Supervision.

\section{Declaration of Competing Interest}

The authors declare that they have no known competing financial interests or personal relationships that could have appeared to influence the work reported in this paper.

\section{Acknowledgements}

Authors are grateful to the anonymous reviewers who provided valuable comments on the early version of the manuscript.

\section{Appendix A. Supplementary data}

Supplementary data to this article can be found online at https://doi. org/10.1016/j.foreco.2021.118931.

\section{References}

Agri4Cast data portal (2020) https://agri4cast.jrc.ec.europa.eu/dataportal/; accessed October 2020.

Allen, C.D., Breshears, D.D., McDowell, N.G., 2015. On underestimation of global vulnerability to tree mortality and forest die-off from hotter drought in the Anthropocene. Ecosphere 6, 1-55. https://doi.org/10.1890/ES15-00203.1.

Ampoorter, E., Baeten, L., Vanhellemont, M., Bruelheide, H., Scherer-Lorenzen, M., Baasch, A., Erfmeier, A., Hock, M., Verheyen, K., 2015. Disentangling tree species identity and richness effects on the herb layer: first results from a German tree diversity experiment. J. Veg. Sci. 26, 742-755. https://doi.org/10.1111/jvs.12281.

Ampoorter, E., Selvi, F., Auge, H., Baeten, L., Berger, S., Carrari, E., Coppi, A., Fotelli, M., Radoglou, K., Setiawan Nuri, N., Vanhellemont, M., Verheyen, K., 2016. Driving mechanisms of overstorey-understorey diversity relationships in European forests. Perspect. Plant Ecol. 19, 21-29. https://doi.org/10.1016/j.ppees.2016.02.001.

Anderson, M.J., Ellingsen, K.E., McArdle, B.H., 2006. Multivariate dispersion as a measure of beta diversity. Ecol. Lett. 9, 683-693. https://doi.org/10.1111/j.14610248.2006.00926.x.

Archaux, F., Wolters, V., 2006. Impact of summer drought on forest biodiversity: what do we know? Ann. For Sci. 63, 645-652. https://doi.org/10.1051/forest:2006041.

Ares, A., Berryman, S.D., Puettmann, K.J., 2009. Understorey vegetation response to thinning disturbance of varying complexity in coniferous stands. Appl. Veg. Sci. 12, 472-487. https://doi.org/10.1111/j.1654-109X.2009.01042.x.

Axmanová, I., Chytrý, M., Zelený, D., Li, C.-F., Vymazalová, M., Danihelka, J., Horsák, M., Kočí, M., Kubešová, S., Lososová, Z., Otýpková, Z., Tichý, L., Martynenko, V.B., Baisheva, E., Schuster, B., Diekmann, M., 2011. The species richness-productivity relationship in the herb layer of European deciduous forests. Glob. Ecol. Biogeogr. 21, 657-667.

Baeten, L., Verheyen, K., Wirth, C., Bruelheide, H., Bussotti, F., Finér, L., Jaroszewicz, B., Selvi, F., Valladares, F., Allan, E., Ampoorter, E., Auge, H., Avăcăriei, D., Barbaro, L., Bărnoaiea, I., Bastias, C.C., Bauhus, J., Beinhoff, C., Benavides, R., Benneter, A., Berger, S., Berthold, F., Boberg, J., Bonal, D., Brüggemann, W., Carnol, M., Castagneyrol, B., Charbonnier, Y., Chećko, E., Coomes, D., Coppi, A., Dalmaris, E., Dănilă, G., Dawud, S.M., de Vries, W., De Wandeler, H., Deconchat, M., Domisch, T., Duduman, G., Fischer, M., Fotelli, M., Gessler, A., Gimeno, T.E., Granier, A., Grossiord, C., Guyot, V., Hantsch, L., Hättenschwiler, S., Hector, A., Hermy, M., Holland, V., Jactel, H., Joly, F.-X., Jucker, T., Kolb, S., Koricheva, J., Lexer, M.J., Liebergesell, M., Milligan, H., Müller, S., Muys, B., Nguyen, D., Nichiforel, L., Pollastrini, M., Proulx, R., Rabasa, S., Radoglou, K., Ratcliffe, S., RaulundRasmussen, K., Seiferling, I., Stenlid, J., Vesterdal, L., von Wilpert, K., Zavala, M.A., Zielinski, D., Scherer-Lorenzen, M., 2013. A novel comparative research platform designed to determine the functional significance of tree species diversity in European forests. Perspect Plant Ecol. 15, 281-291. https://doi.org/10.1016/j. ppees.2013.07.002.

Baeten, L., Bruelheide, H., van der Plas, F., Kambach, S., Ratcliffe, S., Jucker, T., Allan E, Ampoorter A, Barbaro L, Bastias C C, Bauhus J, Benavides R, Bonal D, Bouriaud O, Bussotti F, Carnol M, Castagneyrol B,Charbonnier Y, Chećko E, Coomes D A, Dahlgren J, Dawud S M, De Wandeler H, Domisch T, Finér L, Fischer M, Fotelli M, Gessler A, Grossiord C, Guyot V, Hättenschwiler S, Jactel H, Jaroszewic B, Joly F X, Korichev J, A, Müller S, Muys B, Nguyen D, Pollastrini M, Radoglou K, RaulundRasmussen K, Ruiz-Benito P, Selvi F,Stenlid J,Valladares F, Vesterdal L, Verheyen K, Wirth C, Zavala M., Scherer-Lorenzen M (2019) Identifying the tree species compositions that maximize ecosystem functioning in European forests. J Appl Ecol 56:733-744. DOI: 10.1111/1365-2664.13308.

Barbati A, Corona P, Marchetti M (2007) European Forest Types Categories and types for sustainable forest management reporting and policy, EEA Technical report no. 9/ 2006, 2nd edn. European Environment Agency, Copenhagen.

Barbier, S., Gosselin, F., Balandier, P., 2008. Influence of tree species on understorey vegetation diversity and mechanisms involved-A critical review for temperate and boreal forests. Forest Ecol Manag 254, 1-15. https://doi.org/10.1016/j. foreco.2007.09.038.

Baroni C, Brunetti M, Cerrato R, Coppola A, Betti G, Salvatore M C (2020) A long term chronology of Pinus pinea L. form Parco della Versiliana (Pietrasanta Italy) derived from treefall induced by a windstorm on March 4th-5th, 2015. Dendrochronologia 62: $125710 \mathrm{https} / / /$ doi.org/10.1016/j.dendro.2020.125710.

Baselga, A., 2010. Partitioning the turnover and nestedness components of beta diversity: Partitioning beta diversity. Glob. Ecol. Biogeogr. 19, 134-143. https://doi.org/ 10.1111/j.1466-8238.2009.00490.x.

Berkowitz, A.R., Canham, C.D., Kelly, V.R., 1995. Competition vs facilitation of tree seedling growth and survival in early successional communities. Ecology 76 (4), 1156-1168. https://doi.org/10.2307/1940923.

Bussotti, F., Coppi, A., Pollastrini, M., Feducci, M., Baeten, L., Scherer-Lorenzen, M., Verheyen, K., Selvi, F., 2012. The Italian forest sites of FunDivEUROPE: a new FP7 project on the functional significance of forest biodiversity in Europe. Forest@ 9 (251-259). https://doi.org/10.3832/efor0704-009.

Canullo R, Starlinger F, Granke O, Fischer R, Aamlid D (2016): Part VII.1: Assessment of Ground Vegetation. In: UNECE ICP Forests Programme Co-ordinating Centre (ed.): Manual on methods and criteria for harmonized sampling, assessment, monitoring and analysis of the effects of air pollution on forests. Thünen Institute of Forest Ecosystems, Eberswalde. [http://www.icpforests.org/manual.htm].

Carrari, E., Ampoorter, E., Coppi, A., Selvi, F., 2016. Diversity of secondary woody species in relation to species richness and cover of dominant trees in thermophilous deciduous forests. Scand. J. Forest Res. 31, 484-494. https://doi.org/10.1080/ 02827581.2015.1081981.

Coppi, A., Lazzaro, L., Ampoorter, E., Baeten, L., Verheyen, K., Selvi, F., 2019. Understorey phylogenetic diversity in thermophilous deciduous forests: overstorey 
species identity can matter more than species richness. For Ecosyst. 6, 37. https:// doi.org/10.1186/s40663-019-0191-1.

Davis, K.T., Dobrowski, S.Z., Holden, Z.A., Higuera, P.E., Abatzoglou, J.T., 2019. Microclimatic buffering in forests of the future: the role of local water balance. Ecography 42, 1-11. https://doi.org/10.1111/ecog.03836.

De Frenne, P., Rodriguez-Sanchez, F., Coomes, D.A., Baeten, L., Verstraeten, G., Vellend, M., Bernhardt-Romermann, M., Brown, C.D., Brunet, J., Cornelis, J., Decocq, G.M., Dierschke, H., Eriksson, O., Gilliam, F.S., Hedl, R., Heinken, T., Hermy, M., Hommel, P., Jenkins, M.A., Kelly, D.L., Kirby, K.J., Mitchell, F.J.G., Naaf, T., Newman, M., Peterken, G., Petrik, P., Schultz, J., Sonnier, G., Van Calster, H., Waller, D.M., Walther, G.-R., White, P.S., Woods, K.D., Wulf, M., Graae, B.J., Verheyen, K., 2013. Microclimate moderates plant responses to macroclimate warming. Proc. Natl. Acad. Sci. 110, 18561-18565. https://doi.org/ 10.1073/pnas.1311190110.

Ehbrecht, M., Schall, P., Ammer, C., Seidel, D., 2017. Quantifying stand structural complexity and its relationships with forest management, tree species diversity and microclimate. Agr. Forest Meteor. 242, 1-9. https://doi.org/10.1016/j. agrformet.2017.04.012.

Fernandez-Conradi, P., Borowiec, N., Capdevielle, X., Castagneyrol, B., Maltoni, A., Robin, C., Selvi, F., Van Halder, I., Vétillard, F., Jactel, H., 2018. Plant neighbour identity and invasive pathogen infection affect associational resistance to an invasive gall wasp. Biol. Invasions 20 (6), 1459-1473. https://doi.org/10.1007/s10530-0171637-4.

Felsmann, K., Baudis, M., Kayler, Z.E., Puhlmann, H., Ulrich, A., Gessler, A., 2018. Responses of the structure and function of the understorey plant communities to precipitation reduction across forest ecosystems in Germany. Ann. For Sci. 75, 3. https://doi.org/10.1007/s13595-017-0681-7.

Fotelli, M.N., Rennenberg, H., Holst, T., Mayer, H., Gessler, A., 2003. Carbon isotope composition of various tissues of beech (Fagus sylvatica) regeneration is indicative of recent environmental conditions within the forest understorey. New Phytol. 159, 229-244. https://doi.org/10.1046/j.1469-8137.2003.00782.x.

FunDiv Europe (Functional significance of forest biodiversity) [http://project. fundiveurope.eu/].

Gilliam, F.S., 2007. The Ecological Significance of the Herbaceous Layer in Temperate Forest Ecosystems. Bioscience 57, 845-858. https://doi.org/10.1641/B571007.

Gilliam, F.S., 2014. The herbaceous layer in forests of Eastern North America, 2nd ed. Oxford University Press, Oxford, New York.

Gutschick, V.P., BassiriRad, H., 2003. Extreme events as shaping physiology, ecology, and evolution of plants: toward a unified definition and evaluation of their consequences. New Phytol. 160, 21-42. https://doi.org/10.1046/j.14698137.2003.00866.x.

Guyot, V., Castagneyrol, B., Vialatte, A., Deconchat, M., Selvi, F., Bussotti, F., Jactel, H., 2015. Tree diversity limits the impact of an invasive forest pest. PLoS ONE 10 (9), e0136469. https://doi.org/10.1371/journal.pone.0136469.

Hart SA, Chen HYH (2006) Understorey Vegetation Dynamics of North American Boreal Forests. Crit Rev Plant Sci 25:381-397. https://doi.org/10.1080/ 07352680600819286.

IPCC (2012) Managing the Risks of Extreme Events and Disasters to Advance Climate Change Adaptation, eds Field, C. B. et al., Cambridge University Press.

IPCC (2014). Intergovernmental Panel on Climate Change, AR5 Climate Change 2014: Impacts, Adaptation, and Vulnerability (2014); https://www.ipcc.ch/report/ar5/ wg2/.

Landuyt, D., Lombaerde, E.D., Perring, M.P., Hertzog, L.R., Ampoorter, E., Maes, S.L., Frenne, P.D., Ma, S., Proesmans, W., Blondeel, H., Sercu, B.K., Wang, B., Wasof, S. Verheyen, K., 2019. The functional role of temperate forest understorey vegetation in a changing world. Glob Chang Biol 25, 3625-3641. https://doi.org/10.1111/ gcb.14756.

Kutnar, L., Nagel, T.A., Kermavnar, J., 2019. Effects of Disturbance on Understorey Vegetation across Slovenian Forest Ecosystems. Forests 10, 1048. https://doi.org/ 10.3390/f10111048.

Magno, R., De Filippis, T., Di Giuseppe, E., Pasqui, M., Rocchi, L., Gozzini, B., 2018. Semi-Automatic Operational Service for Drought Monitoring and Forecasting in the Tuscany Region. Geosciences 8, 49. https://doi.org/10.3390/geosciences8020049.

McGillivray, C.W., Grime, J.P., Band, S.R., Booth, R., Campbell, B., Hendry, G., Hillier, S., Hodgson, J., Hunt, R., Jalili, A., Mackey, J., Mowforth, M., Neal, A., Reader, R., Rorison, I., Spencer, R., Thompson, K., Thorpe, P.C., 1995. Testing predictions of the resistance and resilience of vegetation subjected to extreme events. Funct. Ecol. 9, 640-649. https://doi.org/10.2307/2390156.

Morin, X., Fahse, L., Scherer-Lorenzen, M., Bugmann, H., 2011. Tree species richness promotes productivity in temperate forests through strong complementarity between niches. Ecol. Lett. 14, 1211-1219. https://doi.org/10.1111/j.14610248.2011.01691.x.
Mueller, R.C., Scudder, C.M., Porter, M.E., Talbot Trotter, R., Gehring, C.A., Whitham, T. G., 2005. Differential tree mortality in response to severe drought: evidence for longterm vegetation shifts: Drought-induced differential tree mortality. J. Ecol. 93, 1085-1093. https://doi.org/10.1111/j.1365-2745.2005.01042.x.

Nardini, A., Gullo, M.A.L., Trifilò, P., Salleo, S., 2014. The challenge of the Mediterranean climate to plant hydraulics: responses and adaptations. Environ. Exp. Bot. 103, 68-79. https://doi.org/10.1016/j.envexpbot.2013.09.018.

Oksanen J, Blanchet FG, Friendly M, Kindt R, Legendre P, McGlinn D, Minchin PR, O'Hara RB, Simpson GL, Solymos P, Stevens MHH, Szoecs E, Wagner H (2019) vegan: Community Ecology Package.

Oldfield, C.A., Peterson, C.J., 2019. Woody species composition diversity and recovery six years after wind disturbance and salvage logging of a southern Appalachian forest. Forests 10, 129. https://doi.org/10.3390/f10020129.

Ozolinčius, R., Stakènas, V., Varnagirytè-Kabašinskienè, I., Buožytè, R., 2009. Artificial drought in Scots Pine stands: effects on soil, ground vegetation and tree condition. Ann. Bot. Fenn. 46, 299-307. https://doi.org/10.5735/085.046.0406.

Pignatti, S., Menegoni, P., Pietrosanti, S., 2005. Biondicazione attraverso le piante vascolari. Valori di indicazione secondo Ellenberg (Zeigerwerte) per le specie della Flora d'Italia. Braun-Blanquetia 39, 1-97.

Pollastrini, M., Puletti, N., Selvi, F., Iacopetti, G., Bussotti, F., 2019. Widespread crown defoliation after a drought and heat wave in the forests of Tuscany (Central Italy) and their recovery-A case study from summer 2017. Front. For Glob. Change 2, 1-8. https://doi.org/10.3389/ffgc.2019.00074.

Pretsch, H., 2013. Facilitation and competition in mixed-species forests analyzed along an ecological gradient. Nova Act Lc 391, 159-174.

Pretsch, H., Schütze, G., Uhl, E., 2012. Resistance of European tree species to drought stress in mixed versus pure forests: evidence of stress release by interspecific facilitation. Pl Biol 14, 483-495. https://doi.org/10.1111/j.1438-8677.2012.00670. $\mathrm{x}$.

Puletti N, Mattioli W, Bussotti F, Pollastrini M. 2019. Monitoring the effects of extreme drought events on forest health by Sentinel-2 imagery. J Appl Remote Sens. 13.020501 https://doi.org/10.1117/1.JRS.

Putnam R C, Reich P B (2017) Climate and competition affect growth and survival of transplanted sugar maple seedlings along a 1700-km gradient. Ecol Monog 87(1): 130-157 https :// doi.org/10.1002/ecm.1237.

Ratcliffe, S., Wirth, C., Jucker, T., van der Plas, F., Scherer-Lorenzen, M., Verheyen, K., et al., 2017. Biodiversity and ecosystem functioning relations in European forests depend on environmental context. Ecol. Lett. 20, 1414-1426. https://doi.org/ 10.1111/ele.12849.

R Core Team (2018) R: A Language and Environment for Statistical Computing. Vienna, Austria: R Foundation for Statistical Computing. https://www.R-project.org/.

Selvi, F., Carrari, E., Coppi, A., 2016. Impact of pine invasion on the taxonomic and phylogenetic diversity of a relict Mediterranean forest ecosystem. For. Ecol. Manage. 367, 1-11. https://doi.org/10.1016/j.foreco.2016.02.013.

Su, X., Wang, M., Huang, Z., Fu, S., Chen, H.Y.H., 2019. Forest Understorey Vegetation: Colonization and the Availability and Heterogeneity of Resources. Forests 10, 944. https://doi.org/10.3390/f10110944.

Thrippleton, T., Bugmann, H., Kramer-Priewasser, K., Snell, R.S., 2016. Herbaceous Understorey: An Overlooked Player in Forest Landscape Dynamics? Ecosystems 19, 1240-1254. https://doi.org/10.1007/s10021-016-9999-5.

Tinya, F., Odor, P., 2016. Congruence of the spatial pattern of light and understorey vegetation in an old-growth, temperate mixed forest. For. Ecol. Manage. 381, 84-92. https://doi.org/10.1016/j.foreco.2016.09.027.

Warton, D.I., Wright, S.T., Wang, Y., 2012. Distance-based multivariate analyses confound location and dispersion effects: Mean-variance confounding in multivariate analysis. Methods Ecol. Evol. 3, 89-101. https://doi.org/10.1111/ j.2041-210X.2011.00127.x.

Welch, N.T., Belmont, J.M., Randolph, J.C., 2007. Summer Ground Layer Biomass and Nutrient Contribution to Above-ground Litter in an Indiana Temperate Deciduous Forest. Am. Midl. Nat. 157, 11-26. https://doi.org/10.1674/0003-0031.

Wulf, M., Naaf, T., 2009. Herb layer response to broadleaf tree species with different leaf litter quality and canopy structure in temperate forests. J. Veg. Sci. 20, 517-526. https://doi.org/10.1111/j.1654-1103.2009.05713.x.

Zellweger, F., De Frenne, P., Lenoir, J., Vangansbeke, P., Verheyen, K., BernhardtRömermann, M., Baeten, L., Hédl, R., Berki, I., Brunet, J., Van Calster, H., Chudomelová, M., Decocq, G., Dirnböck, T., Durak, T., Heinken, T., Jaroszewicz, B., Kopecký, M., Máliš, F., Macek, M., Malicki, M., Naaf, T., Nagel, T.A., OrtmannAjkai, A., Petř́k, P., Pielech, R., Reczyńska, K., Schmidt, W., Standovár, T., Świerkosz, K., Teleki, B., Vild, O., Wulf, M., Coomes, D., 2020. Forest microclimate dynamics drive plant responses to warming. Science 368 (6492), 772-775. https:// doi.org/10.1126/science.aba6880. 